\title{
A postcolonial framing of Indian commercial surrogacy: issues, representations, and orientalisms
}

\author{
Lisa Lau
}

School of Geography, Geology and the Environment, Keele University, Newcastle-under-Lyme, UK

\begin{abstract}
Although only legalised in 2002, Indian commercial gestational surrogacy (CGS) is an industry worth an estimated 2.3 billion USD to India at its height. Not only has this contentious topic been researched extensively from a spectrum of academic angles, representations of Indian CGS abound in both the Indian and Western popular media (novels, documentaries, films, etc.), and increasingly online, particularly in CGS websites, advertisements, and (personal) blogs. Popular media representations as well as commercial ones can often be inclined towards the sentimental and even sanctimonious, but are immensely influential in shaping public perception. This article seeks to position the discourse and representation of transnational Indian CGS more explicitly within the postcolonial framework. Thus, it addresses a theoretical gap in explicitly connecting the problematic issues of power and ethics in CGS within the paradigms of postcolonial studies, drawing also on gender and feminist frameworks. The neocolonisation of the body has been already considered to some extent - mostly in neo-liberalist contexts - but the industry's systemically orientalistic set up and structure has been surprisingly little mentioned, particularly where transnational surrogacy is involved, with little framing of the imperialistic hangovers and undertones dogging these particular sets of international contracts. This article maps the orientalisms (and sometimes re-orientalisms) at play in this already fraught and contentious context, positioning transnational surrogacy as another instance of imperialism, as yet another form of cultural colonisation, othering, subalternising, and peripheralising working-class Indian surrogate women in the twenty-first century.
\end{abstract}

\section{ARTICLE HISTORY}

Received 3 May 2017

Accepted 23 February 2018

\section{KEYWORDS}

Commercial gestational surrogacy; India; orientalism; postcolonial; representation

\section{Contextualising Indian commercial gestational surrogacy (CGS)}

India's commercial gestational surrogacy (CGS) is just part of its burgeoning medical tourism. Made possible by technological advances, and indeed, made increasingly viable, CGS has burgeoned in the last three decades or so as a thriving

CONTACT Lisa Lau I.lau@keele.ac.uk 
industry in its own right, and India has been at the forefront particularly of transnational or international CGS. In 2002, India legalized CGS; by 2009, reproductive tourism was so much on the rise that one third of surrogacy procedures was on behalf of intended parents living outside India (Harrison, 2014); indeed, by other gauges, 'it is estimated that half of all surrogacy arrangements in India involve foreigners' (Desai 2012). Scott Carney (2010), Sharmila Rudrappa (2015), and other sources seem to agree that the Confederation of Indian Industry predicts surrogacy generates USD 2.3 billion in annual gross profits, with some even estimating revenue to be as high as USD 2.5 billion annually (Bhowmick 2013). 'Each year, an estimated 25,000 foreign couples visit India for surrogacy services, resulting in more than 2000 births' (Bhowmick 2013). It is worth noting, however, that from 2013, gay couples, single individuals, couples married for less than 2 years, and couples from countries where surrogacy is illegal, were prohibited from hiring a commercial surrogate in India; since early 2013, the industry has been servicing only straight or heterosexual couples within India, the United States, Canada, the United Kingdom, Australia, Germany, Spain, and Japan [...] (Rudrappa 2015).

In 2002, and updated in 2005, the Indian Council of Medical Research (ICMR) attempted to provide some guidelines to the 3000 plus clinics involved in the IVF industry which has 'given the appearance of a chaotic, unregulated, and unethical market in fertility services' (Krolokke and Pant 2012, 236). The ICMR's guidelines (e.g. no woman may act as a surrogate more than 3 times, etc.) were recommendatory but did not have the force of law (Munjal and Munjal 2014). Fertility clinics were free to follow or reject the suggestions made by the National Guidelines for Accreditation, Supervision, and Regulation of Assisted Reproductive Technologies (ART) clinics in India issued by the ICMR in 2005 (Pande 2014). With relatively few formal regulations, the CGS industry in India flourished; Amrita Pande and others have identified the other factors working in India's favour as a destination for surrogacy: 'cheap costs, large numbers of well-qualified and English-speaking doctors with degrees and training from prestigious medical schools in India and abroad, well-equipped private clinics, and a large overseas population of Indian origin who often combine cheaper treatment with a family visit' (Pande 2014, 13), not to mention sufficient numbers of lower-middle class Indian women prepared to act as surrogates for sizable recompense.

The costs of surrogacy in India is estimated as ranging from USD 18,000 to USD 30,000 (Bhowmick 2013), or USD 25,000 to USD 30,000 (Jaiswal 2012), or USD 35,000 to USD 45,000 (Rudrappa 2015), or even as low as USD 12,000 to USD 25,000 for the complete medical procedure in India, including the surrogate's fee, airline tickets, and hotel stay for two trips to India (Bailey 2011). Whatever the estimates, most studies seem to agree that CGS in India costs about a third of what it would cost in US, which is anywhere from USD 40,000 to USD 150,000 (Jaiswal 2012, citing the Law Commission of India 2009; Bailey 2011). Sreeja Jaiswal (2012) estimates in India, the surrogate is paid between USD 6000 to USD 10,000, whereas Alison Bailey (2011, citing Gentleman 2008), estimates the surrogate is paid between USD 2000 to USD 
10,000 , with fertility clinics and other brokers, agents, or go-betweens, receiving the rest. (Surrogates in US may receive USD 20,000 to USD 30,000 as their fee.) Pande (2014) and others therefore justifiably underline that CGS is a bargain in India.

This is an interesting juncture in time in which to reconsider - and reposition the debates surrounding the industry of CGS in India, by framing it more centrally within postcolonial conceptualisations. Indian CGS now stands on the brink of being banned by a bill introduced in the Indian parliament by the Minister of Health and Family Welfare, Mr. J. P. Nadda, in Lok Sabha on November 21, 2016. In the transition process that will duly follow this ban, there will be winners and losers. It is interesting to map how the lines have been drawn up by stakeholders in this industry, what claims have been made, what assumptions have been held, heretofore, on which to further map future changes as a result of the passing of the bill. This article has two key aims: firstly, to bring the topic of International Commercial Gestational Surrogacy (ICGS) within the mainframe of postcolonialism studies as a topic of focus in this field of study or discipline, particularly given the industry's colonial history and postcolonial underpinnings, its geographical and social positioning, its power differentials - both within India and between India (as Orient) and the West - and its continued orientalistic and re-orientalistic developments. Relatedly, the second aim of this article is to bring, even preliminarily, postcolonial theories to bear on the analysis of the practises, procedures, and policies within the ICGS industry of India. There has been some early and very worthy work in this direction (detailed in 'Postcolonial framing', the 3rd section of this article); this article calls for the mainstreaming of surrogacy in postcolonial studies. The tools and discourses of orientalism, postcolonial deconstruction, decentering, and etc., are particularly well suited to the unpacking of uneven power relations and exploitations, blatant and concealed, explicit and implicit. The application of postcolonial theory, it is hoped, will be instrumental in challenging existent meta-narratives of ICGS to demonstrate the unevenness of benefits, the vulnerability of certain actors/parties, and the hierarchy of neo-colonial power relationships which are perpetrated and reinforced in the industry.

The next section of this article will briefly highlight some of the key and most current debates surrounding this contentious topic. Following on from that, the article will bring a postcolonial analysis to bear, flagging up the imperialistic nature of this industry, and highlighting neo-colonialisms and orientalisms at play. This article does not seek to rehearse the moralities or issues of justice which is more usually the focus of such discussions; instead, it focuses on the orientalising effects of oft-recurring and commonplace representations which Other, peripheralise, subalternise, silence, marginalise, and misrepresent the industry and the Indian surrogates. Noting the subalternising of the surrogates challenges the metanarrative implying or outright claiming these surrogates are making free and independent choices within this neo-colonial context in which they have to function, highlighting that the element of a choice is more compromised than it may appear to be. 'A complete picture of Indian surrogacy must also be attentive to the ways 
gender, race, ethnicity, caste, and class mediate expectations and assumptions about pregnancy, mothering, and access to reproductive technologies' (Bailey $2011,719)$. This article revisits the paradigms within which the topic of surrogacy have been constructed.

Postcolonial theories usefully forestage issues of representation; postcolonial feminist theorisation is particularly instrumental in pointing out that women in non-Western countries have long been misrepresented, silenced, or distorted in representation, by (i) their patriarchal culture, (ii) the (ironically, paternalistic) universalizing tendencies of mainstream Western feminism, and (iii) as postcolonial subjects, wherein Indian surrogates' intersectionalities lead not just to discrimination and/oppression, but to erasure and silencing. Postcolonial feminism has been said to adopt a transnational focus while intersectionality is 'shaped by methodological localism or nationalism' (Kerner 2017, 847); the addressing of India's ICGS, with its combination of intense localism with globality of practise, encompasses multiple structures of dominance and therefore needs to draw on intersectional gender studies as well as postcolonial feminism frameworks.

\section{The multiple othering of surrogates}

This section reviews the rhetoric and (mis)representations commonly endured/ enjoyed in India's transnational CGS industry, which include the oft-occurring tropes of altruism, rescue, poverty alleviation, neoliberal choice, and empowerment.

From the Oprah Winfrey Show to agents and surrogacy clinics, from blogs to novels, 'surrogacy is celebrated almost unproblematically as "women helping women"' (Fixmer-Oraiz 2013, 144). It is touted, often uncritically, as a mutually beneficial relationship primarily between two women that yields benefits for all parties (Fixmer-Oraiz 2013). So much so, in fact, that surrogacy is framed as a leveller of differences between women, regardless of race, nationality, socio-economic status, as an exchange between equal parties (Harrison 2014). Tapping into the trope of 'women helping women' also serves the purposes of naturalizing surrogacy (Harrison 2014), making it more comfortable for commissioning parents, disguising significant disparities and health risks to surrogates (Fixmer-Oraiz 2013). Natalie Fizmer-Oraiz calls this the rhetoric of altruism, which 'simultaneously reinscribe and exploit gendered and racialized notions of care' $(2013,149)$.

The notion of surrogacy being altruistic or rooted in women-helping-women is rooted in pro-choice rhetoric, of which Charlotte Krolokke and Sauya Pant point out the need to be critical, and to interrogate the notion that that 'global reproductive sisterhood is mutually empowering' (Krolokke and Pant 2012, 237). Fixmer-Oraiz calls for resistance to the seduction of choice which obscures the real issues, detracting from 'rigorous engagement with the unjust conditions under which women do engage in this work' $(2013,147)$ to argue more spuriously about whether women should engage in commercial surrogacy. Indeed, Fixmer-Oraiz goes further in condemning the rhetoric of the global sisterhood by pointing out 
that in masking disparities between commissioning parents and surrogates, 'the global-sisterhood narrative foregrounds these marginalized locations and consequently offers surrogacy as its solution, romanticising surrogacy both as a bridge between overdeveloped and developing nations, and a source of economic and social liberation for Indian women and families $(2013,148)$. So despite the tropes of altruism in commercial surrogacy being linked with global sisterhood or women-helping-women, this rhetoric are exposed as a further means of Othering the surrogates, orientalising them by misrepresentation, and attempting to justify exploitation as actually being in the surrogates' own interests.

More than one critic has also exposed the fallacy and insidiousness of Oprah Winfrey lauding cross-racial CGS as'a beautiful thing' and women-helping-women; this sentimental glossing over not just obscures but rides roughshod over the glaring power differentials and systemic injustices involved. It 'appropriates the feminist language of empowerment, solidarity, and sisterhood' (Harrison 2014, 153), and disingenuously decontextualizes the key players. In fact, Harrison (2014) correctly points out that in this program, the commissioning parents are referred to as 'cultural ambassadors', doing the relationship between Global North and South a disservice by misleadingly extrapolating from the individual to the political, when in actual fact, CGS has not altered the lives of Indian women at the macrolevel, and in fact, represents cultural exchange 'enmeshed in systematically uneven power relations' (Harrison 2014, 153). Harrison (2014) also correctly flags up the implicit class issues embedded in the 2007 episode on Indian commercial surrogacy on the Oprah Winfrey Show, whose inclusion of this topic in this lineup'indicates its places as a social problem worthy of middle-class interest, sympathy, and debate' (150).

Moreover, even the oft-cited reason justifying the use of India surrogates - i.e. the supposedly life-changing income for these working-class women and their families - is another misrepresentation. Pande and Sharmila Rudrappa's extensive fieldwork and data collection are amongst the studies which concur that surrogacy is not usually done by the most desperate and destitute in India, but by the working-classes and/or the lower-middle-classes. For many surrogates, the money earned is approximately 5 years of total family income (particularly in those households where the husband is unemployed or under-employed), but these extended and detailed studies also mostly conclude that in the majority of the cases, the surrogates' and their families' conditions have not actually been drastically changed by the earning of this lump sum of money, nor have they lifted themselves and their families into another income/lifestyle bracket. As Amulya Malladi (2016) represents in her 2016 novel, The House of Happy Mothers, "'Oh, you get the money," Revati continued. "But it's not going to change your life, is it? That's why women keep coming back here. They have one, two, three children like this to make more money while their no-good husbands sit at home doing nothing'"' (227). '[...] the lives of most surrogates did not change [as a result of the payment received]. Some were able to have more control over their earnings than others, but few were able to save up enough to get out of the cycle of poverty. In most 
cases, the money was used up for health emergencies, one-time constructions, and family businesses, and had little effect on everyday life' (Pande 2014, 194). CGS is not therefore a source of employment which can rescue families from relative poverty, though it may alleviate some immediate desperate straits, temporarily. It is often misrepresented as life-changing to provide greater moral justification for commissioning parents and clinics.

While there is a legal debate raging around CGS (particularly from western feminists positions which include freedom for women to contract for labour, the rights of women to sell one's procreative services, and the inherent exploitative and gender stereotyping nature of surrogacy agreements (Qadeer and Arathi 2016, 119)), the very framing of public discourse around CGS - its imagining, articulation, casting, vocabulary - has invoked indignation from critics for upholding and sustaining unjust global systems (Fixmer-Oraiz 2013), for medicalising childlessness in order to commercialise fertility (Nadimpally and Venkatachalam 2016), and for exploiting reproductive labour for profit: 'The dynamics and language and ideas makes things easy for a neoliberal state to appropriate progressive language to its advantage, promote commercialisation and fill in employment gaps with crude work and enhance revenues' (Qadeer and Arathi 2016, 119). Imrana Qadeer and P.M. Arathi also point out that in CGS, framing procreation as labour, the baby is also reduced to a commodity, and the child's rights as well that those of the surrogate are taken away. In a range of ways, therefore, critics have demonstrated how the use of language and discourse in CGS has been created to marginalise surrogates and downplay their rights, as well as to detract from the value of their labour, and to reassert stereotypes.

A further example of the framing of the discourse around CGS designed to Other and marginalise surrogates can be found in the clauses of the proposed bill on ART, drafted (in 2008 and revised in 2010) by the Indian Ministry of Health and Family Welfare (in collaboration with the ICMR), which was an attempt to protect the interest of the intended or commissioning parents, the baby, and the surrogates, in that order, with the gestational surrogate's position downgraded to merely that of being a vessel or carrier (Krolokke and Pant 2012). This positioning of the gestational surrogate was justified on grounds that she has no genetic relationship to the baby - but overlooks the surrogate's biological relationship to the baby, and also disregards the role of fetal cell microchimerism, i.e. cellular interchange between the pregnant woman and fetus (Vora 2015). In fact, in an interview, Kishwar Desai claimed that "Surrogacy contracts - usually kept under wraps - stipulate that the lives of the babies are more precious than the mothers and in case of life-threatening situations, the baby has to be delivered safely' (2012). The order of prioritisation of rights maintains the orientalistic nature of CGS at every step.

Furthermore, Fixmer-Oraiz argues that neoliberalism casts redress for inequities and disenfranchisement'as individual responsibilities within systems of global capital' (2013, 145), and 'obscure[s] reproductive injustice and constrain possibilities for feminist solidarity across borders of race, class, and nation' $(2013,126)$, further 
distorting the rhetoric of choice and subalternising choicelessness. Kalindi Vora also indicts medical sciences and reproductive technology for their 'alienating discourse', utilised by clinics, agents, and others involved in the Indian CGS industry, to distance the nature of gestation and childbirth from surrogates' bodies, isolating 'the reproductive body and gametes from the social context in which they originated', which in turn renders women apparently "'free" to sell gestation and childbirth as services to commissioning parents who are "free" to hire these services from women as labor' $(2014,72)$.

Along with the oft-cited tropes of altruism, of women from Global North and South as mutual beneficiaries, of choice, of individual responsibility for poverty, there is also the trope of rescue. The circulation of the ideology of CGS being a form of rescue or poverty relief for Indian surrogates, is concealed within 'the lack of economic privilege working-class Indian women experience because of their class and global race locations' (Rudrappa and Collins 2015, 956), and positions CGS as solution rather than symptom of global capitalism's profound social and economic injustice (Fixmer-Oraiz 2013). Although a complete picture of Indian surrogacy 'must also be attentive to the ways gender, race, ethnicity, caste, and class mediate expectations and assumptions about pregnancy, mothering, and access to reproductive technologies' (Bailey 2011, 719), the larger picture of uneven globalization in terms of international division of labour is frequently obscured or left unnoticed and undiscussed, left out of the CGS discourse, and with telling effect. In fact, Rudrappa and Caitlyn Collins (2015) tell us bluntly that the tropes of rescue and altruism in particular, are gross misrepresentations which have failed to take into account the existent inequities and deeply uneven playing field. They contend that '[t]his reproductive imaginary is a myth' (Rudrappa and Collins 2015, 956), because the very structural factors rendering working-class Indian women such a good fit for surrogacy is what enables the imaginaries of benevolence and rescue from poverty. However, interestingly, the trope of rescue for Indian surrogates is occasionally also approached from an opposite angle, regarding surrogacy as'an exploitative practise from which Indian women must be rescued' (Bailey 2011, 724). Bailey contends that surrogacy is too often represented as a binary, either of exploited surrogates, or else of contract pregnancy as a free choice with a win-win outcome. Yet another false rescue-trope is used in the ultimate Othering of the surrogate in framing the baby as needing rescue: in Lisa Ling's report for the 2007 Oprah Winfrey Show, India is Othered repeatedly, with its 'unruly nature'foregrounded, deliberately showcasing the American commissioning parents as out of place in India, with the implication that their baby is 'a temporary foreigner in an exotic land (the country as well as the body of the surrogate) waiting to be rescued by its 'real' parents' (Harrison 2014, 151). The legacy of colonial plunder and the ruthless utilisation of the 'native' body for western profit continues to cast a long shadow.

Most representations, particularly media representations and representations in the popular imaginary, justify and rationalise CGS by stressing the issues of poverty or need in connection with financial compensations from surrogacy work. 
'The global press routinely reinforces the connections between poverty and surrogacy work, creating the impression that contract pregnancy is the opportunity of a lifetime' (Bailey 2011, 718). In popular media, the surrogates' stories are presented as workers being grateful for and glad of the chance to be surrogates, how it is a better option than any other choices available to them, the best source of income they can access, a help to their very survival and that of their families and even extended families, the chance to educate children, build a house, pay off debts, meet medical expenses, etc. In this particular representation, surrogates are depicted as altruistic and practical decision makers; '[t] he rhetorical focus here is on opportunity, choice, and fair exchange' (Bailey 2011, 719).

The Baby M era also induced a dramatic shift in the public persona of surrogacy: 'The magic of the global market has transformed surrogate mothers from selfishcrazy, deceitful, and manipulative con artists like Mary Beth Whitehead and Anna Johnson into the rational, autonomous, ends-choosers of liberal; theory and global capitalism. (Bailey 2011, 722).

Much of the representation concerning commissioning parents is intensely focused on personal narrative and mainly on the anguish and pain (particularly that of the intended mother) of the struggle with infertility. Fixmer-Oraiz (2013) notes the insidiousness of underscoring narratives with this uneasy mixture of despair with entitlement, which refuses analysis in favour of sentiment, crafting a profile of infertility 'that is raced, classed, and gendered' (136). In flagging up that this particular narrative of infertility is unrepresentative, Fixmer-Oraiz is also pointing out that it performs (and is facilitated by) class and colour privileges, which in turn, even if inadvertently, silences other narratives in the transaction of surrogacy: 'The popular narrative of infertility [...] is overwhelmingly white and class privileged' $(2013,136)$, reifying white women as' rightful and legitimate mothers', normalizing motherhood as' fulfilment of white, class-privileged womanhood' $(2013,137)$. This simultaneously refuses a critical analysis of infertility as social injustice and embedded within systems of oppression, 'making underresourced women and communities largely invisible within this discursive terrain' (ibid). Moreover, as Harrison (2014) points out, when a woman of colour gives birth to a white baby, it is all too easy to identify her as 'Other' yet again, further weakening her maternal claims and 'naturalizing the authenticity of the relationship between child and intended parents' (150).

In an analysis of the 2007 Oprah Winfrey Show which told the story of an American couple going to India to seek ICGS, Harrison (2014) highlights that sitting side by side, with the surrogate's face completely covered with a shawl, Jennifer West [the American intended mother] speaks for Sangita [the surrogate] - just as Flaubert had spoken for Kuchuk Hanem (Said 2003) - and moreover, 'in a language that Sangita [the surrogate] likely does not understand, while Sangita is literally and figuratively invisible' (Harrison 2014, 152). The effacement of the surrogate, her unheard story, all amounts to the further subalternisation of the Oriental and the Orient once more. 
Critics have also picked up on how the very language used in surrogacy orientalises. Baumhofer (2012) reminds us that the very term'surrogate' talks to our patriarchal structures, as a'surrogate' serves the man, a surrogate wife with which to bear his child. Fixmer-Oraiz (2013) observes a gradual shift in rhetoric in reference to the surrogates: from 'birth mother' to 'surrogate mothers' to 'gestational mothers' to 'surrogate,' and now, most commonly, 'gestational carrier' (151), which increasingly devalues the labour and alienates the kinship of the surrogates. Moreover, the metaphor of 'outsourcing', by which surrogacy is increasingly compared to, 'situates the Wests [the commissioning parents] in the place of powerful multinational corporations, with Sangita as the cheap and disposable labor' (Harrison 2014, 153).

As in many colonial discourses, the orientalisms within ICGS are frequently projected onto the bodies of third world women. Technological medical advances too are frequently inscribed on the bodies of the poor and the female.

Harrison (2014) notes how not only is India Othered in mainstream US representations of Indian ICGS, its Othering stresses the traditional Orientalist trope of the Other being excessive, particularly in sexuality and fecundity; 'hegemonic antinatalist propaganda portrays the fertile bodies of lower-class women in the global South as recklessly reproductive and to be blamed for their poverty' (Pande 2016 , 248). However, the orientalistic representation is designed to indicate 'the ripeness and fertility that such wildness can produce at the behest of the infertile Americans' (Harrison 2014, 151). This is deeply ironic, because 'infertility itself is disproportionately suffered by low-wealth communities and communities of color and inextricably tied to a range of social-justice issues, such as lack of access to adequate health care' (Fixmer-Oraiz 2013, 136).

Moreover, in a further ironic twist, many studies have pointed out that in India, working-class women have historically been aggressively targeted for sterilization, and yet are the same women targeted as surrogates (Bailey, 2011). (Rudrappa (2015) points out most Indian surrogate mothers have been permanently sterilized female sterilization is far more common in Indian than in any other country - and it tends to be the lower classes which are sterilized, whereas better educated and wealthier women are more likely to use the pill, condoms, IUDs, than their less privileged counterparts). Moreover, India also has a particularly poor record on women's health and extraordinarily high maternal mortality rates (Rudrappa 2015). Bailey (2011) raises the troubling questions of whether there is not something 'unsettling' about requiring those very Indian women, who are already treated 'as second-class citizens at the very best, and as property or financial liabilities at the very worst' (734), to perform draining and intimate bodily work, limit their own families, risk their own long-term health, all in order to carry children for wealthier couples. Being globally positioned in a category which lacks economic privileges, 'because of their class and global race locations', Rudrappa and Collins contend working-class Indian women's bodies can therefore become'sites for drastic medical interventions' (typically entailing hormonal hyperstimulation and major abdominal surgery (Rudrappa and Collins 2015)), their very bodies forming the 
material basis for the industry $(2015,956)$,'a site of consumption for white intended parents' (Harrison 2014, 150).

Orientalisms have traditionally been colour-based, and ICGS is no different, raising the spectre of eugenics as well as discrimination. To begin with, and even apart from ICGS, '[h]igher-class, lighter-skinned women within India are still paid more than their lower-status, darker-skinned counterparts' (Peet 2016, 182) and their behaviours less heavily policed and limited as surrogates. Indeed, educated urban women of higher status and lighter skin earn an average of USD 2000 more than their counterparts (Peet 2016). Bailey (2011) contends that research findings clearly indicate traits such as fair skin, lighter hair, blue/green eyes, high IQs, are greatly in demand by Indian couples coming to fertility clinics, and that color and caste also play a central role in the surrogacy's negotiating power; a fair-skinned, educated, middle-class Brahman who speaks English will fetch more. This is despite the fact these are all gestational and not traditional surrogates, who are therefore not genetically related to the fetus. Bailey extrapolates that concerns over the skin colour of surrogates are code for concerns about their moral characters:'It appears that the racial markers that have historically marked light-skinned women as good mothers and dark-skinned women as bad mothers have been extended to mark 'good' and 'bad' wombs' (2011, 720). The orientalising strategy of insistence on moral binaries aligned to colour, continues to be a dominant discourse in discussing surrogates and their value.

Not only is it easier, as Bailey and other critics have raised concerns about, for the bodies of poorer and coloured women to be commoditised, the market itself may be driven by a demand for lighter-skinned babies. Desai (2012) also argues that international commissioning parents too look for'fairer babies with coloured eyes, bringing into the picture women from Europe and Ukraine as surrogates especially in countries like India. Donors with good educational qualifications and achievements are sought after'. It is worth quoting Daisy Deomampo (2016) at length here:

Indian medical doctors draw attention to the marketlike aspects of gestational surrogacy and egg donation, comparing the process of creating a life (with specified phenotype or skin color characteristics) to simple consumer choices' $(304,305)$. Gamete donation, for instance, has precipitated a return to ideas of genetic and racial essentialism, in which sperm and egg donor profiles are scrutinized for certain traits, with the promise of inheritable phenotypic and skin colour characteristics, among other features. [...] sperm and egg donation practices in the United States reflect positive eugenic beliefs in new and more subtle forms (309).

Deomampo's research explores how commissioning parents pursuing ICGS in India negotiate the process of 3rd party egg donation. Contradicting dominant assumptions that intended parents seek donors who match their own racial/ethnic backgrounds, her research found that many sought Indian egg donors with darker skin tones. But this does not subvert racial hierarchies privileging white skin, or prove resistance to racialized preconceptions, because these choices continue to 
be deeply orientalistic, and 'rely on essentialized notions of race and beauty and reflect new articulations of biological race' (Deomampo 2016, 306). Indeed, from her work, Deomampo concludes 'preferential treatment based on skin color, or colorism, is widespread' $(2016,308-309)$.

Deomampo's riveting research found the existence, openly and commonly, of two 'lists' in separate files or databases, which doctors within fertility clinics in India typically maintain: the A-list, or diva list, of more beautiful donors, and the darker donors (who are of more similar backgrounds to the surrogate). In these files, 'skin color nearly always overlapped with education, class, and beauty' (317). Deomampo's work also noted that nationality and skin colour both influence payment, with white egg providers receiving higher pay than Indian providers. (Deomampo (2016) reported that Indian egg providers/donors receive from USD 180-360, while white providers from South Africa received USD 2200. Another doctor said A-list donors can get USD 2000, while other donors get USD 630. Another doctor claimed to pay USD 2000 for an oriental donor.)

It is also worth noting the concern over fair skin is not just a demand of the intending parents or end-consumers, but actively promoted by Indian doctors and clinics who enable and facilitate this tiered practise. So concerned are Indian doctors with the 'matching' of physical characteristics of intended parents and fetus - ' the language of 'resemblance' and 'matching' serves as a neutralized proxy for race' (Deomampo 2016, 310) - that even special requests from commissioning parents for darker egg donors may not be heeded by the doctors.

The issue of race, if somewhat euphemised and obscured by the language of 'resemblance' and 'matching' in Indian terms, in Western terms is so fraught that it is the proverbial elephant in the room, only ever referred to tangentially, no matter how central or dominant it actually may be. In the aforementioned Oprah episode, Harrison (2014) astutely exposes that 'race is primarily discussed in euphemistic terms: the physical 'difference' cited between the Wests and their surrogate Sangita is not that of race but of size. [...] the difference in size stands in for a discussion of racial difference, with the large, robust American depicting wealth, health, and white Western dominance' (151) Harrison also notes that Oprah Winfrey (the host), Lisa Ling (the reporter), and the Wests (the commissioning parents), 'repeatedly downplay and explicitly deny the spectre of class and race-based exploitation, size is a safer measure of difference than skin tone or nationality' (ibid). It would appear that that certain Orientalisms (e.g. racism or classism), finding a contemporary lack of purchase, may yet exist in camouflage - hence the usage of euphemisms (such as size). Just as cultural racism seems to have replaced biological racism, where the term 'white' can be substituted with 'European' or 'Western', Harrison (2014) seems to have picked up that the Oprah episode attempts to substitute'race' with 'size' in denial of the racial element which speaks all too clearly of imperialistic overtones in the transaction between Sangeeta and the Wests, the conflating of size and race an attempt to deny and even disown the power disparity. 
Although many Western commissioning parents may reject the Indian doctors' kinship models which privilege whiteness by regularly opting for Indian egg donors, these parents are nevertheless not without culpability in practising orientalisms. Deomampo's work found that commissioning parents often conflated ideas of race with nationality and culture, and some opined that gestation (not merely genes) bestowed on the children some degree of Indian heritage and identity. Deomampo points out how attached some intended parents become to the Indian 'Origin story' of their children even if the child was not conceived using Indian gamates, returning from India with symbolic emblems including Indianinspired clothing, home décor, even Indian names for their children. Deomampo argues that 'flattening out' the specificity of India and its historical and political contexts, the parents 'conflated the geographic space of India - and the attendant orientalist discourses that construct 'Indian-ness' as exotically opposite to Western sensibilities [...]' $(2013,151)$. Even the best-intentioned of commission parents who reject race and colour discriminations, may still be guilty of other orientalisms, such as exoticising, essentialising, and homogenising.

\section{Postcolonial framing}

Being a contentious topic on a number of fronts, Indian ICGS has been researched extensively from a spectrum of academic angles (as partially summarised in the preceding section), ranging from feminists and political scholars arguing the exploitation of (gendered, classed, raced) labour; legal and moral justice scholars debating citizenship, laws, regulations of the surrogacy industry and the participating countries; and philosophy and cultural studies scholars looking at issues of new family structures and the redefinintion(s) of parenthood. Heretofore, Indian ICGS has perhaps been most searchingly and robustly studied from the anthropological angle, analysing the rhetoric of choice, agency and (dis)empowerment, kin labour, the tyranny of technology, North-South relationships, cultural context, reconstruction of kinship ties; and of course not forgetting the (socialist and Marxist) economics of globalisation which lies at the heart of commercial surrogacy, given that this industry was enabled and driven by technological medical advances, unequal global power and economics, and sufficient and sufficiently easy access to transborder exchanges (of information, money, commodities, medical facilities). In this wide-ranging academic discussion of Indian ICGS, there have been just a few - too few - mentions of or nods towards postcolonialism. In this section, this article highlights the connections between imperialism and the issues within Indian ICGS, which are too often overshadowed by more dominant gender and ethics discourses.

The framing of India's ICGS within the postcolonial can be roughly divided into three areas, which are not distinct one from the other, and indeed, feed into each other. Foremost perhaps is the historical relationship between India and the West. Vora (2015) usefully points out that 'histories of medicine as a technique 
of extracting resources from human bodies and disciplining subjects intersect with legacies of British colonialism in India, where the historical role of Western medicine was as a tool of colonial subjectification and the British civilising mission' (89-90). The body, particularly that of the abject, and particularly the female body, has always been a site of colonial contestation and inscription. 'The existential life of the racialized body has been harsh, subject not only to the indignities of the auction block, to rape, branding, lynching, whipping, stun gunning, and other kinds of physical abuse' (Shohat 1997, 202), and we may possibly add to this grim list, surrogacy, which further encrypts a twenty-first century, technologically highly advanced, but still rather colonial subjugation of the Indian female body.

Vora further argues that the role India has played this century in providing ART services globally, of being the location for Western outsourcing of wombs and pregnancies, 'has historical roots in India's relationship to Western medicine and in the international division of labour in British colonial practices' $(2015,89)$, where the colonies were regarded as sites for plunder of resources and raw material to supply the colonial centre. Moreover, the valuing of skin colour and class backgrounds of donors, not to mention donor eggs, continue to extend what Deomampo calls 'an economy of color reflective of a history of colonisation and racism' (2016, 317). Fixmer-Oraiz (2013), Bailey (2011) and other critics have also called attention to 'the oppressive dimensions' of the reproductive globalized industry of ICGS, flagging up the industry's 'discursive colonization' and 'moral absenteeism', and too often conveniently concealed imperialistic roots.

This historical foundation of the imperialistic relationship between India and the West continues to underlie the relationship between the commissioning and/ or intended parents, and the surrogates. Commissioning parents are also benefitting from historical and contemporary neo-imperial relationships between the West and the developing world which both appropriate and devalue care labor performed by people of color, particularly women in the Global South' (Peet 2016, 179-180). Indeed, they are not just benefitting, but, Vora would argue, situated to take advantage 'as the result of their own stratified histories, and as such bring those histories to bear upon their connection to India and the contracted relationship to the surrogate' $(2015,86-87)$.

Sayantani DasGupta and Shamita Das Dasgupta (2010, cited in Kroløkke and Pant, 2012) point out the difficulties of an egalitarian swap in a transnational CGS transaction, highlighting neo-colonial and orientalist practices in subjecting pregnant Indian bodies to the objectifying Western gaze, and even in the framing of these women as 'good Hindus' (i.e. non-smoking, non-drinking, non-drug-using bodies), and therefore, ideal surrogacy vessels. Orientalistically, ICGS transactions keep the whip hand in the West, as significant discrepancies of wealth, power, and resources persist between the commissioning parents and surrogates, which 'engages histories of power and difference established in India's colonial history' $(2015,91)$, and which has been not only exploitative, but heretofore, legally protected. 
The colonial legacy, the historical grooves, the existent Global North-Global South division of labour in globalisation, prefigure and pre-program modern day ICGS transactions even if many of the parties involved refuse to recognise this. 'When commissioning parents travel to Indian and engage with ART clinics and Indian surrogates, they connect Indian histories with other geographically-specific historical legacies, such as class relations and histories of servitude, in those sending countries. [...] much as the former colonial metropoles have benefitted from a similar exploitation of what world systems theory named "the peripheries"'(Wallerstein 1976, cited in Vora 2015, 90). As such, whether or not commissioning parents are aware of the wider geo-political and historical implications, they are more often than not complicit in extending imperialistic practises in the process of utilising transnational CGS services.

The relationships of unequal power are not only between agents of Global North and Global South, but also within India, in the re-orientalism of the working-classes by the elite and upper-classes, that is to say, the re-orientalism of surrogate women by Indian medical practitioners, Indian fertility clinics, Indian law-makers, Indian brokers, and Indian commissioning parents. All too often, re-orientalism is at the service of imperialism, facilitating exploitation and even safe-guarding its continuation. 'A relationship of power between the Indian middle and upper-middle classes, here the doctors running the clinic and elite Indian commissioning parents, and the rural, less-educated, less-connected, and much lower-resourced women they hire to act as gestational surrogates represents in part a continuity with India's colonial past' (Vora 2014, 80).

Drawing on the work of David Arnold (1993) and Gyan Prakash (1999), Vora (2015) advocates for a thinking which brackets the newness of technologies with historical continuities, 'Subaltern and postcolonial studies approaches to medicine in colonial India have also explained the way in such an economic climate, the suppression of indigenous interests is common in the development of social and economic policies that advance the interests of economically and politically dominant classes' (Vora 2015, 99). It is important to maintain a postcolonial focus on ART and CGS, Vora argues, because the devaluing of surrogates in India is part of the culturally imagined mind-body separation, leading to the notion of the instrumentalised uterus, which is related to 'the role that medicine and medical education have played in India's colonial and postcolonial history' $(2015,100)$.

Rudrappa and Collins (referencing Lewis 2015) have pointed out the hypocrisy of how infertility businesses in India'posit themselves as social businesses, an ethical capitalism that ameliorates inequalities resulting from First World infertility and Third World poverty' $(2015,953)$. This insistence on the advantage for the exploited is in typically colonialist and orientalist vein, reinforcing the meta-narrative that subjugation benefits the subjugated, and is hence thus legitimised. The power of legal and medical practitioners and brokers in the CGS industry is extended by their being the voices of the industry, having the power to represent, which is denied to the subalternised surrogates. 


\section{The orientalisms of Indian CGS}

It has been long argued that Indian women are twice-colonised, by the British and by their patriarchal tradition, but there could possibly be an argument for the fact that Indian surrogate women may be thrice-colonised: as Arturo Escobar points out, 'development managed to modernize patriarchy, with grave consequences for Third World women' $(2012,173)$. The globalized rhetoric of mainstream popular culture, media, and social media, and issues of representation as controlled by orientalistic power structures, mean that women's labour is easily commodified, and their rights downplayed or even downgraded. These issues of representation and rhetoric cannot be underestimated in their influence and power to shape the lives of Indian women, and as Fixmer-Oraiz argues, mainstream imaginaries, 'actively work to frame and justify the sale of reproductive labors and bodies across borders. These rhetorical processes matter profoundly to the crafting of public policies, attitudes, and beliefs that continue to shape the cultural terrain in which commercial surrogacy is authorized and practiced' $(2013,146)$.

Edward Said had famously used the example of Flaubert's encounter with an Egyptian courtesan to illustrate the workings of orientalism, the dominance of the Western representation of the East;

which produced a widely influential model of the Oriental woman; she never spoke of herself, she never represented her emotions, presence, or history. He spoke for and represented her. He was foreign, comparatively wealthy, male, and these were historical facts of domination that allowed him not only to possess Kuchuk Hanem physically but to speak for her and tell his readers in what way she was'typically Oriental'. (Said 1978, 6)

In similar vein, we find that apart from a handful of studies which interviewed Indian surrogate women, the vast majority of mainstream representations of Indian ICGS is by cultural producers (mainly in the West), not by Indian surrogate women themselves, who unsurprisingly have little access to platforms for selfrepresentation. Of the voices from India dominating the discourses of ICGS, it is the relatively elite in Indian society - the doctors and administrators of fertility clinics, the brokers and agents - but once again, seldom the Indian surrogate women themselves. For Said (who first coined the notion of imagined geographies in 1978), imagined geographies shape real geographies, just as discourses, rhetoric, and representations of ICGS shape the practises and norms of ICGS, that is to say, the dominant discussants of ICGS shape its regulations and the experiences of its relatively subalternised surrogates.

In reviewing some of the key areas of academic debate within Indian ICGS, this article has found that many of its problems of representation overlap with those Said identified with Orientalism: 'My fears are distortion and inaccuracy, or rather the kind of inaccuracy produced by too dogmatic a generality and too positivistic a localized focus' (Said, 2003, 8). In ICGS, the narratives which have misrepresented surrogates and the industry of ICGS range from misrepresentation of the conditions under which ICGS is practised, to misrepresentation of motives and 
outcomes. This article has discussed the falsity of claims that ICGS lifts surrogates and their families out of poverty, that it is mutually beneficial for commissioning parent and surrogate, that it is empowering for all women involved but particularly for the surrogates (because it is allegedly done out of altruism, liberating, poverty alleviating), and that that ICGS transactions are a bridge between developing and developed nations.

One of the long-standing problems of transactions between practitioners of Global North and South is the unchanging nature of the unequal power relationship, where the Global North retains the upperhand. As orientalism theory has flagged up, the Orient is fixated as timeless, silent, passive, malleable, which renders it perfect for Western/Occidental extraction of services and resources, and in the twenty-first century, that includes the gestation of babies and the renting of wombs. The Orient has also been long essentialised in feminised and infantilised terms, as justification for Western conquest, which is not just geographical domination, but includes the medical and socio-economic. Furthermore, the Orient (through Western lenses) has been cast from the outset as prone to despotism and corruption, depraved in certain ways, which is conversely convenient when siting an industry that is dangerous, unregulated, but hugely profitable. Applying Orientalism theory to an analysis of the Indian ICGS industry reveals its deeply and continuing imperialistic nature, insidious and yet largely unquestioned. Furthermore, postcolonial feminists theorists like Gayatri Spivak, Chandra Mohanty, Susheila Nasta, Meyda Yegenoglu, Ann McClintock and others have long pointed out the position of Global South women as veiled (literally and metaphorically), as voiceless, and as victims. In a range of (fairly imaginative) ways, the surrogate is subalternised and silenced, peripheralised despite being the key to the industry's deliverables.

The'first-colonisation' of Indian surrogates is the colonial legacy which remains largely ignored, enabling the dismissal of often unjust power imbalances where the Global North decidedly maintain the upperhand. The sidelining or erasure of the imperialistic basis on which the CGS industry functions conceals disparities of income, socio-economic status, lack of choice, exploitations, and disregards the inherent unevenness stemming from colonial legacy.'Imperial legacies undergirding contemporary practices of outsourcing also mean that we must pay attention to how we understand the politics of reproduction and labour in emerging forms of biological production and reproduction in general' (Vora 2015, 91).

Orientalism theory also points out how Othering happens when the Self - in this case the intended or commissioning parents - is prioritised at every turn. Occupying the 'Centre' space, commissioning parents' (especially transnational ones') preferences are typically more highly ranked and taken into first consideration, their wishes accommodated, even if necessary, at the expense of the rights and wishes, and even needs and risks of the surrogates.

The second-colonisation of Indian surrogates is enabled by the patriarchal system of their society. Postcolonial feminism identifies that other women and fellow 
countrymen can be subalternising forces. Although subjected to the larger neoimperialist forces of globalization, the Indian surrogates are also re-orientalised by those closest to them, their families, the brokers who introduce potential surrogates to the industry, the clinics and staff of the industry. The willing complicity of the elite of India with the Global North - the willing complicity of Indian politicians and medical practicioners and brokers - is yet another colonial legacy, a practise of re-orientalism where Orientals perpetrate orientalisms as enthusiastically as Occidentals in complicity with the ruling classes or dominant power groups.

It is even possible the Indian surrogates are unwittingly self-orientalising. The Indian surrogate women are in a sense covertly subalternised in having less autonomy in decision-making than may first appear, and perhaps even than they themselves are aware of or would wish to acknowledge. There are several possible reasons: one being that the Indian surrogates find it more empowering to claim they make choices autonomously, which enhances their financial contribution to the family via payments for surrogacy. Secondly, many families of surrogates opine that it is a team effort, not just that of the individual surrogate, with some justification as the family often has to rally round to give the surrogate time to perform this surrogacy and delivery. However, perhaps the most likely factor is that 'surrogate mothers did not perceive themselves as victims or as people brutalized in their employment in markets in life. [...] Bangalore's surrogate mothers, operate in 'states of denial" (Rudrappa 2015, 169). However, ignorance or denial of positions of vulnerability do not then change the reality of precariousness, and may in fact further jeopardise or put at greater risk their health, their rights, and their abilities to make truly autonomous decisions.

The 'third colonisation' or the thrice-colonising of Indian surrogates is of course the forces of globalization. Commissioning parents, for whom parenthood is a part of their development and journey to self-fulfilment, depend on the exploitation of the need of Indian surrogates in precarious socio-economic situations. The banning of non-Indian commissioning parents, if the ART Bill is successfully passed, is no guarantee of improved circumstances for Indian surrogates. If ICGS from India is banned, the two likeliest outcomes is that either this industry moves to other 'soft' markets (perhaps Thailand, for example) which would encounter exactly the same problems and issues as it already does in India, thus merely changing the location of the problem rather than solving it; or else ICGS in India may be driven underground into the black market, making it even more difficult to regulate, more easily exploited, and riskier for a number of stakeholders, particularly the donors and surrogates; or in a worst case scenario, both these outcomes may simultaneously come to pass. Recognising that knowledge can be a charter for domination, and that orientalism has long been a Western technique for having authority over the Orient, it is easy to see how both the elite of India and the Global North are complicit in restructuring the very language and discourse, the very framing and representation of CGS in India. A meta-narrative is created which disingenuously depicts a win-win situation, suppressing the stories of the suffering of surrogates, 
the risks they run, the costs to their health and families, the longer-term costs which are neither factored in nor considered. (For e.g. some surrogates surrender the chance to have another child of their own, in order to carry out surrogacy; others feel they have shortchanged their families of a family member in 'giving away' a baby; others have had to require their families to make sacrifices or do extra labour in order to accommodate the surrogacy arrangement; others even compromised their long-term health, serving as egg donors and/or surrogates) What is often left out of this angle/narrative, is the depiction of the situation for these women, their lack of resources and choices. 'Can fully autonomous health and employment decisions be made under these conditions?' (Bailey 2011, 734), is a question that simply fails to even be asked. The most misleading of all angles, is the assumption that because there are large numbers of available surrogates in India, this proves it is a good thing for Indian women who are apparently queuing up to sign on as surrogates. As is typical in orientalism and re-orientalism, this is a misrepresentation used to legitimise exploitation, as surrogates are not made aware of how far demand in fact outstrips supply, in order that they do not negotiate harder for higher wages; the suppression of knowledge also being an orientalist technique of control.

In sum, the practises of Orientalism within CGS and ICGS are many and varied. Misrepresentations abound, leading to the entrenchment of unjust practises and the reinforcement of class, colour, race hierarchies. A recognition of the underlying colonial foundations and continued imperialistic trends of CGS globally, would be a significant tool in exposing the exploitations inherent in the industry and its transnational transactions. A repositioning of ICGS within the postcolonial feminist framework would go a long way in assisting the understanding of its many (and gross) misrepresentations, which orientalistically influence and shape the very realities it depicts. Postcolonial studies, postcolonial feminisms, and feminist geographies too, are some of the conceptual frameworkings which already critique knowledge construction and legitimisation, hegemony, and oppressive knowledges, calling for more situatedness and reflexivity; and as such, these could help deconstruct the Indian ICGS industry insightfully. It is by applying orientalism theories and other postcolonial tools that the surrogacy industry can be further analysed to reveal its imperialisms, deep-rooted structural injustices, and systemic power disparities.

\section{Acknowledgements}

I would like to thank GPC's editors and peer reviewers for their thoughtful comments and careful feedback which has been invaluable in the reworking of this paper.

\section{Disclosure statement}

No potential conflict of interest was reported by the author. 


\section{Notes on contributor}

Lisa Lau pioneered and developed re-orientalism theory and discourse. She co-authored Re-Orientalism and Indian Writing in English (Palgrave, 2014) and co-edited Re-Orientalism and South Asian Identity Politics: The Oriental Other Within (Routledge, 2011). Her key areas of research include postcolonialism, gender studies and South Asian Literature in English; with a focus on power, narrative, identity construction, class chasms, social and cultural change, and the diaspora. Lisa has also worked extensively on issues of representation, co-authoring Indian Writing in English and Issues of Visual Representation: Judging a Book by More Than Its Cover (Palgrave, 2015). Her research on representation also includes work on the topics of cosmopolitan returnee migrants, hospitality, and commercial surrogacy.

\section{References}

Arnold, David. 1993. Colonizing the Body. Berkeley: University of California Press.

Bailey, Alison. 2011. “Reconceiving Surrogacy:Toward a Reproductive Justice Account of Indian Surrogacy." Hypatia 26 (4): 715-741.

Baumhofer, Emma. 2012. Commodifying the Female Body: Outsourcing Surrogacy in a Global Market. Thinking Gender. UCLA conference.

Bhowmick, Nilanjana. 2013. "Why People Are Angry about India's New Surrogacy Rules." Time, February 15. Accessed March 3, 2017. http://world.time.com/2013/02/15/why-people-areangry-about-indias-new-surrogacy-laws/

Carney, Scott. 2010. “Inside India's Rent-a-Womb Business." Mother Jones, March/April. Accessed February 20, 2017. http://www.motherjones.com/politics/2010/02/surrogacy-tourism-indianayna-patel

Deomampo, Daisy. 2013. “Gendered Geographies of Reproductive Tourism.” Gender and Society 27 (4): 514-537.

Deomampo, Daisy. 2016. "Race, Nation, and the Production of Intimacy: Transnational Ova Donation in India." Positions: East Asia Cultures Critique 24 (1): 303-332.

Desai, Kishwar. 2012."India Becoming a Designer Baby Factory." Times of India, August 2. Accessed March 3, 2017. https://uk.news.yahoo.com/india-becoming-designer-baby-factory-authorkishwar-desai-042015758.html

Escobar, Arturo. 2012. Encountering Development: The Making and Unmaking of the Third World. Princeton, NJ: Princeton UP.

Harrison, Laura. 2014. "I Am the Baby's Real Mother': Reproductive Tourism, Race, and the Transnational Construction of Kinship." Women's Studies International Forum 47: 145-156.

Jaiswal, Sreeja. 2012. "Commercial Surrogacy in India: An Ethical Assessment of Existing Legal Scenario from the Perspective of Women's Autonomy and Reproductive Rights." Gender, Technology and Development 16 (1): 1-28.

Kerner, Ina. 2017."Relations of Difference: Power and Inequality in Intersectional and Postcolonial Feminist Theories." Current Sociology 65 (6): 846-866.

Kroløkke, Charlotte Halmo, and Sauya Pant. 2012. "'I Only Need Her Uterus': Neo-Liberal Discourses on Transnational Surrogacy." NORA-Nordic Journal of Feminist and Gender Research 20 (4): 233-248.

Lewis, Sophie. 2015. The Doyenne of Surrogacy on TV: Dr. Patel's Mediations of Contract Pregnancy's Uneven Geography. http://www.academia.edu/13810171/The_Doyenne_of_ Surrogacy_on_TV_Dr_Patel_s_Mediations_of_Contract_Pregnancy_s_Uneven_Geography. Malladi, Amulya. 2016. A House for Happy Mothers. Seattle, WA: Lake Union Publishing. 
Munjal, Diksha, and Yashita Munjal. 2014. "The 'Wanted' Child: Identifying the Gaps and Challenges in Commercial Surrogacy in India." Asian Bioethics Review 6 (10): 66-82.

Nadimpally, Sarojini, and Deepa Venkatachalam. 2016. "Marketing Reproduction: Assisted Reproductive Technologies and Commercial Surrogacy in India." Indian Journal of Gender Studies 23 (1): 87-104.

Fixmer-Oraiz, Natalie. 2013. "Speaking of Solidarity: Transnational Gestational Surrogacy and the Rhetorics of Reproductive (in)Justice." Frontiers: A Journal of Women Studies 34 (3): 126-163.

Pande, Amrita. 2014. Wombs in Labor. Transnational Commercial Surrogacy in India. New York: Columbia UP.

Pande, Amrita. 2016. “Global Reproductive Inequalities, Neo-Eugenics and Commercial Surrogacy in India." Current Sociology 64 (2): 244-258.

Peet, Jessica L. 2016. "A Womb That is (Not Always) One's Own." International Feminist Journal of Politics 18 (2): 171-189.

Prakash, Gyan. 1999. Another Reason: Science and the Imagination of Modern India. Princeton, $\mathrm{NJ}$ : Princeton University Press.

Qadeer, Imrana, and P. M. Arathi. 2016. "Words, Ideas and Ideology in the Shifting Sand of Markets." Indian Journal of Gender Studies 23 (1): 105-132.

Rudrappa, Sharmila. 2015. Discounted Life. the Price of Global Surrogacy in India. New York, NY: New York UP.

Rudrappa, Sharmila, and Caitlyn Collins. 2015. "Altruistic Agencies and Compassionate Consumers: Moral Framing of Transnational Surrogacy." Gender and Society 29 (6): 937-959.

Said, Edward. 2003. Orientalism. London: Penguin.

Shohat, Ella. 1997. "Post-Third-Worldist Culture: Gender, Nation and the Cinema." M. Jacqui Alexander and Chandra Talpade Mohanty (eds). Feminist Genealogies, Colonial Legacies, Democratic Futures. New York, NY: Routledge.

Vora, Kalindi. 2014. "Experimental Sociality and Gestational Surrogacy in the Indian ART Clinic." Ethnos 79 (1): 63-83.

Vora, Kalindi. 2015. "Re-Imagining Reproduction: Unsettling Metaphors in the History of Imperial Science and Commercial Surrogacy in India." Somatechnics 5 (1): 88-103. 